\title{
Ontological Openness on the Lurujarri Dreaming Trail: a Methodology for Decolonising Research
}

\author{
Nia Emmanouil \\ Southern Cross University \\ nia.emmanouil@scu.edu.au
}

Keywords: ontological openness, ontological politics, Lurujarri Dreaming Trail, songline, Goolarabooloo, decolonising research, land use disputes.

\begin{abstract}
The Lurujarri Dreaming Trail is an ancestral dreaming track ${ }^{1}$ near Broome in the Kimberley region of north-western Australia. Walked each barrgana ${ }^{2}$ season by Goolarabooloo traditional custodians and non-Indigenous people, this trail was also recently the site of a major land use dispute. Conflicts over what the land is and how it should be valued have defined Indigenoussettler relations since the first wave of colonisation of Australia's First Peoples and their ancestral estates (Wilson \& Ellender, 2002). At the heart of these conflicts are different ways of conceptualising and relating to the land, and ultimately, divergent ontologies. ${ }^{3}$ This paper reflects on my doctoral research and the recent dispute in the Kimberley which foregrounded my research, to contribute to conversations on how research methodology can recognise the ontological politics (Verran, 2007) enacted in place. It explores how I, as an ethnographic researcher, used ontological openness to work ethically and productively with the different realities being performed in place. It also explores the broader implications of this approach in terms of decolonising research practice and supporting respectful dialogue between Indigenous and Western peoples and realities.
\end{abstract}

\section{Landing in Broome: Meeting the Goolarabooloo Community and Country}

The flight into Broome always ends with a sweeping arc over the milky blue waters of Roebuck Bay (fringed by red pindan earth and mangroves) and a low fly-over Chinatown and the historic Sun Pictures. The intensity of these colours seared into my memory when I first arrived in Broome in the year 2000. I was an undergraduate student from RMIT University who had travelled to the Kimberley to walk the Lurujarri Dreaming Trail with the Goolarabooloo Indigenous community.

1 Dreaming tracks trace the pathways of ancestral creators. Embedded within these pathways are traditional knowledge, stories, songs and law, which contain codes of behaviour for balanced relationships. In the West Kimberley, this body of cultural knowledge and law is referred to by the name Bugarrigarra (Wilcox, 2010, p. 26).

2 Barrgana is the season when cool winds blow from the southeast (July - August). In the ocean walgawalga (salmon), catfish, galbany (mullet) and jugan (dugon) are fat and the whales are migrating north. On the land, yarrinyarri (bush onion) are plentiful and can be dug out of the shallow sands (Goolarabooloo, 2013). Indigenous language words written in this paper appear in italics and originate from the Nyulnyulan family of languages, including Bardi, Jabirr Jabirr, Ngumbal, Nyulnyul, Jugun and Yawuru (Muecke \& Lowe as cited in Kelly, 2016).

3 In this paper, ontology is taken to mean the nature of existence and being, which takes into account categories that structure what is (Fielbleman, 1960, p. 219). The term is also used to reference ways of being, and to provoke a questioning of the realities that people enact (Law, 2004, p. 162). 
This year marks 30 years since Nykina and Goolarabooloo Elder Paddy Roe OAM established the cross-cultural walking of the Lurujarri Dreaming Trail. Paddy's motivation for inviting nonIndigenous Australians to walk the land with his people is evocatively captured in the statement:

This is why this [dreaming] trail I got. You know I was thinking about how we can come together and this [Trail] is the only way we can come together to look after the Country. (in Whitmont, 2010)

All journeys along the Lurujarri Dreaming Trail begin under a broad old tamarind tree at the Goolarabooloo Hostel in 'old Broome'. It is here that Paddy's family, the Goolarabooloo people, welcomes walkers hailing from many places and cultural backgrounds to Country. ${ }^{4}$ Over nine days and 90-kilometers, this eclectic 'mob' of walkers trace the pathways and patterns of ancestors and creator beings, camping in the same seasonal camping places that have been dwelled in for thousands of years. Located on the west coast of the Dampier Peninsula in the Kimberley region of Western Australia (see Figure 1), this ancestral dreaming tract, otherwise referred to as the Northern Tradition Song Cycle, is an entity that connects with other song cycles $^{5}$ that cross the Australian continent. The Trail is a constitution of human, more-thanhuman and ancestral relations that are invoked and maintained as people walk through, with and as Country.

For nine days we walk along the Lurujarri coast, through mayi (monsoonal vine thicket) and along sandy beaches and rocky cliff tops. At sundown we unfurl dusty swags onto red pindan or white sand, tying mosquito nets to the branches of murga (Melaleuca alsophylla, saltwater paperbark). Smokey fires ward off persistent mosquitoes, infusing hair and cloth with the smells of gunaroo (Eucalyptus zygophylla, white gum) and jigal (Bauhinia cunninghamii). We sit grounded, cross-legged in sand and dust, amongst the murga. They fringe our camps, sheltering us from the south-easterly winds that blow across this country during barrgana time. Each year we return to the same buru (camping or highly significant spiritual place). The same ground is re-visited and old fires are re-lit, ashes mounding up. Remnant coals glow once more under fires that dot dry, sandy creek beds.

In walking the Trail I was one in a continuum of students to carry on RMIT's long-standing relationship with the Goolarabooloo community, a relationship that began in the 1990s through the friendship of Paddy Roe and Landscape Architecture academic Jim Sinatra. My first and subsequent journeys along the Lurujarri Dreaming Trail in the years 2007 and 2011, and further time spent camping on Country with Goolarabooloo families during 2000 and 2001, enabled me to form lasting relationships with people and place. These relationships 'called' me back to Broome in 2011, at a time when the Northern Tradition Song Cycle and Lurujarri Dreaming Trail faced a major threat from a proposed industrial development. It was in this context of such significant personal relationship, to both people and place, and the depth of concern I had for what could happen, that my research emerged.

4 In this paper the term 'Country' refers to a place-based ontological entity that exists for Indigenous Australians. Burarrwanga (in Burarrwanga et al., 2013) describes Country as a totality of many things, including multiple layers of meaning: 'It incorporates people, animals, plants, water and land. But Country is more than just people and things, it is also what connects them to each other and to multiple spiritual and symbolic realms' (p. 128). Stated otherwise, 'Country includes humans, more-than-humans and all that is tangible and non-tangible and which become together in an active, sentient, mutually caring and multidirectional manner in, with and as place/space' (Country et al., 2016, p. 456).

5 Bradshaw and Fry (1989) describe song cycles as manifestations of the creative journeys of ancestral beings, through which 'stories, ceremonies, laws and rituals are passed between communities' ( $p$. 7). These stories about the journeys of creative ancestors are invoked through song-poetry to form oral maps of the country. Wilcox (2010) states that 'a person who knows the songs can travel through the country and stay in a sustaining relationship with it' (p. 26). 


\section{Conflict, Ontological Politics and the Emergence of a Research Project}

The context of this research was inextricably shaped by conflict and ontological politics over place. This conflict was sparked by the proposed siting of the Browse Liquefied Natural Gas processing plant at Walmadany (James Price Point), approximately 60 kilometres north of Broome, by the West Australian (WA) Government, Woodside and their joint venture partners. ${ }^{6}$ My research became a way to draw attention to a radical difference in the way that place was being enacted by different parties.

Figure 1: Map of the Lurujarri Dreaming (Heritage) Trail

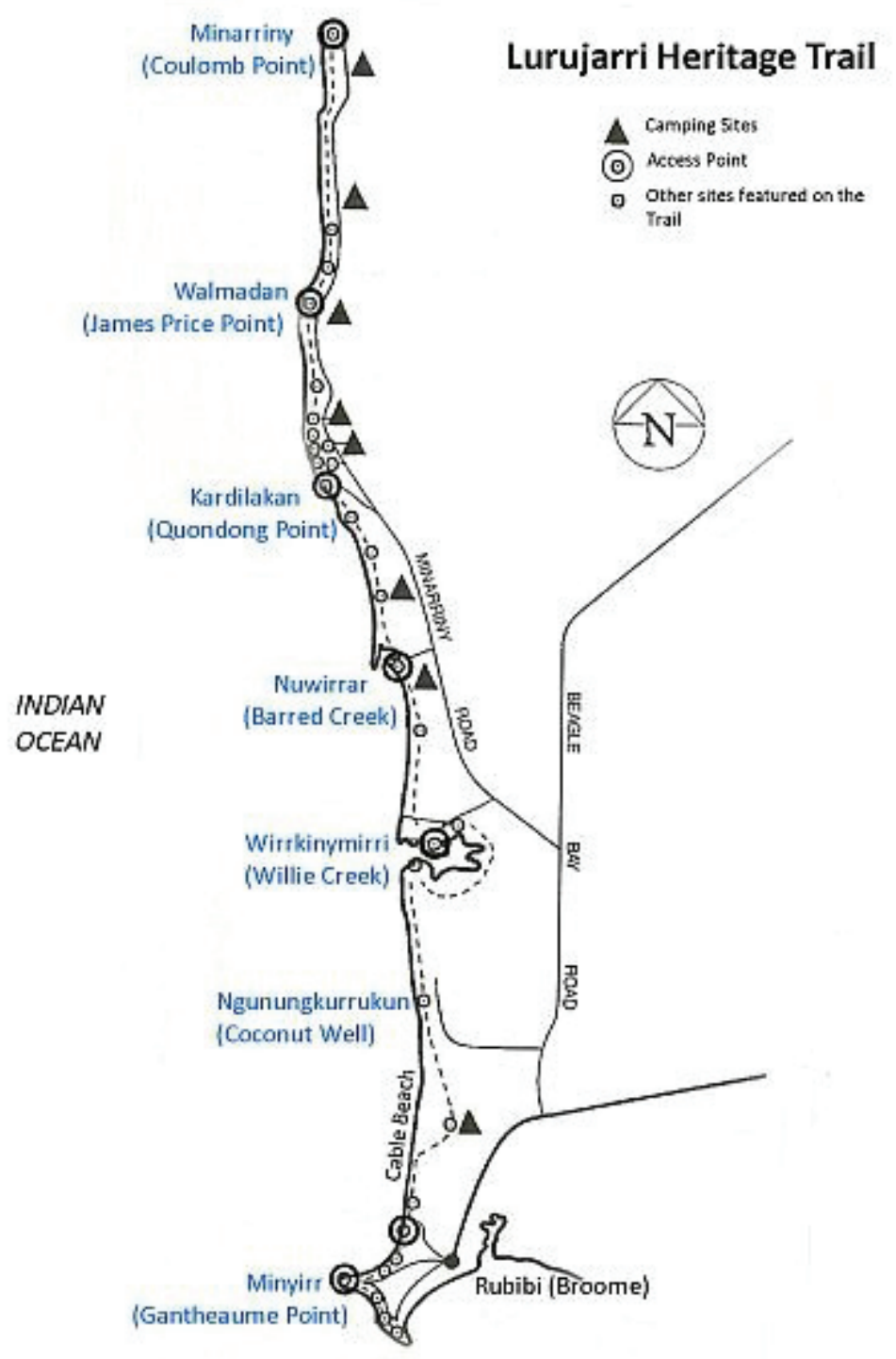

Source: Goolarabooloo (2013).

6 The WA Department of State Development was the key proponent for the development of a land-based LNG processing plant at Walmadany/James Price Point. At the time of writing my doctoral thesis from between 2012 and 2016, the joint venture partners to this development were Woodside, Mitsui, PetroChina, Shell and BP. For many people in Broome and on the Dampier Peninsula, this development was colloquially referred to as 'The Gas'. 
I mobilised the concept of ontological difference to reveal what was being missed in the conflict being played out around 'The Gas'. Proponents of this development and the Goolarabooloo people were enacting very different relationships with place. For the WA Government and the mineral resources industry the Browse Basin and land at James Prices Point (the place name used by the proponents) represented commodities, ${ }^{7}$ shareholder profits and mining royalties, pointing to a very particular ontological position. Yet, the Goolarabooloo people were 'seeing', relating to and speaking about the same place from a very different worldview: James Price Point was recognised as 'Walmadany', a highly significant cultural heritage site along the Song Cycle path where the Jabirr Jabirr ancestor Walmadany continues to live. The land was not a commodity to exploit, but 'Country', a multi-dimensional entity with which a person can experience reciprocity of care and to which they have a responsibility to maintain and enliven.

The Goolarabooloo people unequivocally opposed the industrial development of Walmadany (Whitmont, 2010). Such development posed an imminent threat to the integrity of the Northern Tradition Song Cycle, including, the law and culture that emerge from Bugarrigarra, ${ }^{8}$ which are embedded in and practiced with the Song Cycle, and people's material and spiritual connections with Country. In an interview with documentary filmmaker David Maybury-Lewis (1992), Paddy Roe emphasised the relationship between Bugarrigarra and law.

Law -

That's Bugarrigarra, Law -

I think English say-

'dreamtime' -

But we say Bugarrigarra -

Law.

Sitting on the veranda of his home in the Milibinyarri community, Paddy Roe's great-grandson Brian Councillor described this same relationship in the context of the Song Cycle. He stated emphatically, ${ }^{9}$

[It] is like a snake. You give [Woodside] that snake, he'll break him in half, it'll never join back together. That Song Cycle he strong right through from Swan Point right down to Bidyidanga. But [Woodside and the State Government] don't understand that. You break that snake, you break that Song Cycle, and then what we got left? Culture and everything will finish. It's just sad. That's what we live for. We live for our culture, our law. If our law and culture get broken, what we gonna do then? (in Emmanouil, 2016, p. 217)

7 Wilson and Ellender (2002) describe commodified land as 'something that can be bought, sold, exchanged and exploited, with no significant or lasting relationship between the 'owner' and the land other than a commercial one' ( $p .56)$.

8 When Paddy Roe speaks about Bugarrigarra in Reading the Country (see Benterrak, Muecke \& Roe, 1984, p. 78), he invokes his jila (spring) Country out on the Roebuck Plains and the yungurugu (Rainbow Snake) which lives there: a spirit being that emerges from Bugarrigarra, which can make cyclones and heavy rain. Paddy belongs to, has responsibilities for, and is located in Bugarrigarra, and explains in this text how Bugarrigarra still works: people are doing important work to keep it going and do their part in this process of ongoing co-creation, and the maintenance of culture and lawful relationships with Country. Paddy Roe's collaborator, Stephen Muecke (2017), describes Bugarrigarra as a legal institution that continues to come into 'friction' with colonial/settler law.

9 In my doctoral research Brian and several other participants shared their stories in Broome English, a type of Australian Aboriginal English that is distinct to the Broome area (Brumby as cited in Sandefur, 1986, p. 26). More broadly, the term Australian Aboriginal English is used to refer to a spectrum of dialects spoken by Aboriginal and Torres Strait Islander Australians, each of which incorporates creole and Standard Australian English to varying degrees (Saderfur, 1986, p. 25). 
Brian's story helped make apparent to me the contestation over place that was unfolding on the Trail; contestation over what the land is (e.g. Country and a Song Cycle, or, commodity) and what it does (e.g. provide reciprocity of care and hold Law and culture, or, offer a means of economic stimulus in the neoliberal sense). His and the stories of others walking the Trail drew my attention to the divergent values systems, metaphysics (including ontologies) ${ }^{10}$ and ontological politics ${ }^{11}$ that were being performed in place. The apparent refusal of the WA Government to 'take seriously', or even acknowledge entities such as 'Country' and the 'Song Cycle', highlighted for me the ongoing ontological and epistemological dominance of a Western, 'Euro-centric' worldview, and the subsequent neo-colonisation (Dodson, 2007) of people-place, a phenomenon that Rose (1999) articulates as 'deep colonisation' and Muecke (2017) 'neoliberal extraction colonisation'. The ontological politics at play on the Trail offered a focus and context for doing research that would intervene in and disrupt this neo-colonial agenda.

\section{Being a Generative Participant in the Collective Action to Protect Country}

In 2011 my relationships with people and Country led me to Broome to support the Goolarabooloo-led community campaign ${ }^{12}$ to protect the Song Cycle and the Trail. I soon realised that my involvement in this collective action offered me a way to situate myself as a researcher, in the role of a 'generative participant' (Addelson, 1994). ${ }^{13}$ By acknowledging myself as already a generative participant in the campaign to protect Country, I was able to intervene in issues (Addelson, 1994) and recognise the relational context (Wilson, 2008) of my research.

My friendships with the Goolarabooloo community, non-Indigenous walkers of the Trail and people protecting Country, along with my personal connections with place, meant that I held a relational accountability (Wilson, 2008) to both people and Country. Being relationally accountable meant enacting respect, reciprocity and responsibility towards my human and more-than-human (e.g. Country) research collaborators. A fundamental methodological question arose when I acknowledged this relational accountability. How could I, as nonIndigenous ethnographer, work ethically and productively with Country, Goolarabooloo people and non-Indigenous walkers of the Trail, their realities and the stories that emerge from people-place connections, when there were likely to be multiple knowledge systems and ontologies at play? My ethical accountability needed to go beyond merely avoiding ontological and epistemological 'blindness' (as exemplified by the WA Government in relation to the Song Cycle). I needed to ensure that as a researcher, I was able to translate my own and others' lived experiences of walking the Trail into stories that could do justice to the Trail as performing a profound politics. This is turn meant recognising the multiple Indigenous and non-Indigenous realities being performed as people walked through, with or as Country. Hence, it became critical for me as an ethnographer to question my own 'ontological openness'.

10 Noticing divergent ontologies being enacted in and with place is one thing, naming them in a text (like a thesis or a paper) is another. I deal with the issue of naming ontologies in the section titled 'Actor-Network Theory'.

11 On the subject of ontological politics Helen Verran (2007) emphasises the need for people to 'make explicit [their] metaphysical commitments and so interrupt and create possibilities for considering re-rendering [their] worlds' (p. 36).

12 The Kimberley 'No Gas' campaign enrolled diverse communities and groups of people, including the Goolarabooloo families, other local Indigenous and non-Indigenous families in Broome and on the Dampier Peninsula, local and national environmental organisations, citizen science groups, globally renowned scientists, scholars and performing and filmic artists, ex-members of the judiciary and supporters from around the world.

13 This positioning is distinct from the role that researchers are commonly expected to assume; that of the 'judging observer' who through a humanist lens, creates artificial divisions between themselves and the world. 
Relationality was the core ethical principle underpinning my research. Along with respect, reciprocity, responsibility and deep listening, it also became the protocol that guided this work. After I invited Goolarabooloo people, non-Indigenous walkers of the Trail and allies of the Goolarabooloo who were protecting Country to share their stories about their relationships with Country (many of whom I had known for over a decade), we sat together with and as Country to record these stories. Attending to my relationships with not only human research collaborators, but also the Country and the stories themselves, was a practice that required me to listen deeply with my liyan (feeling, intuition, connection) (Roe \& Hoogland, 1999). The storytelling did not happen (either at the direction of the participants or unfavourable circumstances) when the right liyan or 'feeling' with the place, person or time was absent. When the storytelling did happen with good liyan, the stories themselves seemed to carry something; keep something from Country moving.

\section{Creating a Methodology for Ontological Openness}

How could I perpetuate and continue on the political statement of the Trail in the face of the conflict over development? I needed a methodology that would enable me to demonstrate the importance of recognising the different way that place was being enacted on the Trail by the Goolarabooloo, walkers and protectors; an alternate reality that contested the version of place being 'done' by the WA Government and mining corporations. In responding to this question, I gravitated towards approaches that promoted ontological openness.

Several writers working in cross-cultural contexts offered insights into how I, a researcher located in and seeking to evolve a Western knowledge tradition, might embody ontological openness in my research.

Deborah Bird Rose (2004) highlights the tension between vulnerability and productivity inherent in approaching cross-cultural work with 'openness', in which 'one's own ground can become destabilised' (p. 22). Being open to encountering and experiencing 'other' realities enabled me to negotiate my 'metaphysical commitments' (Verran, 2007, p. 39) and in turn, undergo ontological and epistemological shifts. Yet, these shifts only occurred gradually through being 'there' on and with Country (Wright et al., 2012) - camping, sleeping, storytelling and walking - and by listening deeply (Brearley, 2010) to the stories shared by Goolarabooloo storytellers with and as Country and the stories shared by Country itself. ${ }^{14}$

Lurujarri Dreaming Trail co-ordinator Frans Hoogland describes what the Goolarabooloo people hope walkers (perhaps even me as a researcher) will comprehend during their journey along the Trail:

People are introduced to the song cycle through direct experience of walking and being with it, trying to understand the living quality of that Country. That has to be experienced. It's very hard to grasp that out of reading books or through people talking. It's a very personal experience. (in Roe \& Hoogland, 1999, p. 27)

14 Writing as 'an Indigenous and non-Indigenous, human and more-than-human research collective' Bawaka Country, Wright, Suchet-Pearson, Lloyd, Burarrwanga, Ganambarr, Ganambarr-Stubbs, Ganambarr and Maymuru (2015) acknowledge Bawaka Country as the 'author-ity' of their research and describe a process of co-becoming with Country, which enables deep relational learning and stories to emerge from, with and as place/Country. 
Understanding the livingness of Country through the direct experience of being with and walking the Country might also be described, as 'being and knowing ... intelligence and cognition' (Banting, 2013, p. 428). As Frans critically points out, this cannot be apprehended through 'reading books', it must be experienced first-hand.

David Mowaljarlai and Jutta Malnic (1993) share another instance of ontological opening experienced in a cross-cultural context. Malnic, a woman of Western heritage, reveals a moment when she becomes aware of the shifts she must allow to 'see' the world that Mowaljarlai, a Ngarinyin Elder, is sharing with her:

In the darkness I scrawl some words into my notebook. In the morning they hang there like a magician's rope, coming from nowhere, not touching ground, a reminder that I had understood something during the night - but what? The words read: "You can only see with your eyes closed. Be patient”. (Mowaljarlai \& Malnic, 1993, p. 87)

Patience was crucial to my research practice, as was being open to learning in ways that I had never before imagined: through dreams (Turner, 2010), liyan (feeling and intuition) (Roe \& Hoogland, 1999) and allowing things to be revealed by County rather than 'discovered' (Graham, 2009). Doing ontologically open research forced me to de-centre the human as the primary source and holder of knowledge (Graham, 2009; Rose, 1988) and acknowledge the agency of Country to 'share' knowledge embodied within the land (Graham, 2009; Guyula, 2010; Turner, 2010; Wright et al., 2012). Hence, practicing ontological openness led to not only a recognition of Indigenous forms of knowledge production, but also the performance of such methods; it enabled me to know with Country.

Reimagining my own knowing (and being) with the world through the research process meant that I needed 'new categories and ... [to rework] old categories in new ways' (Verran, 1998, pp. 241-242) when telling ethnographic stories. Yet, which categories and metaphors would I use to render visible the realities that others and I were performing? Wright et al. (2012) also questioned the ontological limitations of attempting to describe human connections with the land and the agency of Country merely through Western categories. What I was coming to see was that 'to describe the real is always an ethically charged act' (Law, 2009, p. 155). As an ethnographer, I carried a responsibility for telling stories in a way that maintained the ontological integrity of people's relationships with place. My storytelling needed to reflect a deep listening (Brearley, 2010) to people-place; those stories shared with me by storytellers on/with/as Country, including Goolarabooloo people and non-Indigenous walkers of the Trail, and a deep listening to Country itself. I listened closely to the categories and metaphors that storytellers used when speaking about place and their connections with place, which revealed the human and non-human entities that constituted people's realities.

Well aware of the legacy of negative impacts brought upon Indigenous peoples by ethnographic research (Smith, 2012), I was responsible for finding ethnographic 'tools' that would enable me to work respectfully, ethically and with relational accountability with human and non-human entities made visible by participants' stories, and through my own walking with Country. As a non-Indigenous researcher I was hesitant about appropriating an Indigenous research framework. In following the work of Verran (1998) and Nicholls (2009), who write about Indigenous ontologies and epistemologies as powerful actors, I was led to Actor-Network Theory (ANT). Verran (1998) used ANT to trace enactments of land ownership in Australia by pastoralists and Indigenous Australians and to question the ontological categories that inform people's relationships with land. Nicholls (2009) took ANT into the Yolnu township of Ramingining to explore the life of the computer amongst the powerful actors of gurrutu (the 
Yolnu kinship system), moiety and online banking. These two instances indicated to me that there was a way to 'do' ethnography that could respect Indigenous peoples and place and the metaphysics they enacted.

\section{Actor-Network Theory}

Actor-Network Theory (ANT) enabled me to encounter and describe the different ways that place was being enacted, for example, by walkers of the Trail and by those who were proposing the Browse LNG development. Rather than assume that knowledge was being performed on the Trail through Western scientific practices, it allowed 'space' to consider alternate, and in this case relational (Indigenous) knowledge practices. Hence, as an approach to research, ANT became a way of identifying and mobilising difference. I was able to use ANT to show that realities were being enacted through knowledge practices; the actions of enacting Country though walking, camping and fishing on, with and as Country (and the Song Cycle) produced a differing people-place to scientific or other Western means for enacting people and place, which tend to be binary.

ANT emerged from Science and Technology Studies (STS) in the late 1970s and early 1980s and began as an ethnographic approach to sociotechnical analysis. My attraction to ANT as a form of 'relational materiality' (Law, 1999, p. 4) was due to its non-discriminatory, heterogeneous approach to entities; 'human' and 'non-human' entities were equally as likely to have agency, as long as they did some type of 'work'. ANT's willingness to take seriously the agency of all entities, including 'non-human' entities such as and within 'Country', meant that it presented an ontologically open, and I would argue decolonising, method for doing ethnographic research.

There was another key justification for selecting ANT as a research approach. In my reading of ANT and Indigenous philosophy (metaphysics) literature (Benterrak, Muecke \& Roe, 1984; Mowaljarlai \& Malnic, 1993; Rose, 1996, 2000, 2004; Turner, 2010; Ford, 2010; Bessarab, 2008; Hoogland \& Roe, 1999; Kwaymullina, 2008; Neidjie, 1989; Harrison \& McConchie, 2009; Bradley \& Yanyuwa Families, 2010; Christie, 2007), it became apparent that four patterns or 'principles' were emerging from both: relationality, performativity, generative practice and situatedness/locatedness.

Each of the aforementioned patterns/principles contributes, in some way, to the relationships that Indigenous peoples (tend to) perform with Country. For example, Country, 'Dreaming' and story are powerful ontological concepts that inform people's meaning, structures, situatedness, identities, relationships with human and non-human entities and responsibilities towards cogenerating the ongoing-ness of Country. Writing about ANT and its metaphysics, John Law (2009) identifies and draws links between the same four patterns/principles that underpin this method. He describes ANT as (note the underlined terms in the quotation below):

a disparate family of material-semiotic tools, sensibilities, and methods of analysis that treat everything in the social and natural worlds as a continuously generated effect of the webs of relations within which they are located. It assumes that nothing has reality or form outside the enactment of those relations. (emphasis added, Law, 2009, p. 141)

Framed in ANT terms, relationships are performed by actors through particular activities and in particular situations/locations, generating particular effects. Resonance between ANT and Indigenous philosophy, through these four principles, offered 'ground' on which ANT and Indigenous metaphysics could enter into dialogue and potentially 'work together'. 
As an ethnographer, ANT charged me with the responsibility to look closely for the 'observable traces' (Latour, 2005, p. 53) that were left by any entities/actors, ${ }^{15}$ 'no matter how vague' an actor might be (Latour, 2005, p. 53). While many actors were easy to identify, owing to their material form, others were less palpable and tricky to name for some research collaborators, particularly non-Indigenous walkers of the Trail. Despite difficulties in naming some actors, I was encouraged by Fenwick and Edwards (2010) to persist with this approach. They state that:

Whether an object [or entity] is more or less abstract ... is not the point. The key feature is that it is identified, has reality, in particular networks of historical, cultural, behavioural relations that make it visible. (Fenwick \& Edwards, 2010, p. 18)

While ANT was ontologically open and responsive to human and non-human, material and non-material entities that performed people-place relationships on the Lurujarri Dreaming Trail, constant work was required by me to ensure that I was staying open to any 'type' of actor that might 'appear'.

What did appear through my use of ANT on the Lurujarri Dreaming Trail, was a vibrant assemblage of actors, including, Goolarabooloo storytellers, Trail walkers, red pindan cliffs, ancestors, räi (spirits) a certain proximity to town, women's places, mamara (spirit trees) and traditional camping places to name a few. ${ }^{16}$ What also became visible, were the associations between these actors, what held these connections together and at what cost. For example, liyan (as intuition and feeling) surfaced as an important and complex actor that supported both the formation and maintenance of people-Country connections, by enabling people to attune to the liyan (feeling) present in Country. Once awoken, through the process of walking Country and by the agency of the spirit world (räi), a person's liyan allowed them to engage with Country through inter-subjective encounters. The active engagement of both people and living Country in these relationships enabled powerful collaboration between these actors.

Furthermore, sustained connections between Country and people (Goolarabooloo and some walkers on the Trail), produced relationships of care, where mutual recognition and communicative engagement were also being performed. Despite threats to these connections, including from the proposed Browse LNG processing plant, human and non-human actors found ways to stay connected.

ANT proved to be a very useful lens and a practical set of tools with which to do restrained ethnographic work that held me back from making ontological assumptions. It enabled me as a researcher to listen and to watch; to see more actors than I might have otherwise seen, precisely because it did not prescribe any ontological categories that might preclude my 'seeing'. In turn, no actors or voices were disallowed through the use of ANT.

Did this mean that I met, recognised and acknowledged everything there was to be seen, heard or perceived and understood in some way? Did I always acknowledge all of the actors at work in each scenario I researched? No. But this was not a limitation of ANT. Rather it is the lot of researchers to be constrained by time and place and influenced by interests. However, did ANT prove wholly adequate in doing ethnographic work with Indigenous epistemologies and ontologies on the Lurujarri Dreaming Trail? In short, yes. ANT's instance on relationality,

15 Put in the simplest of terms, ANT uses the word 'actor' to refer to any human or non-human entity that does work.

16 These entities were identified by Goolarabooloo and non-Indigenous research participants. 
performativity, generative practice and locatedness/situatedness, principles that resonate deeply with Indigenous ontologies, meant that it had the capacity to do respectful and honest work alongside Indigenous epistemologies and ontologies to explore the performance of different people-place relationships on the Lurujarri Dreaming Trail.

Perhaps most valuably, ANT allowed me to make visible in my academic writing the divergent ontologies being performed on the Trail. The WA Government, mining companies and others associated with 'The Gas' (e.g. economist and scientists) were performing their relationships with James Price Point through distance via their boardrooms in Perth, practicing what Latour (1987, p. 251) calls metrology: the process used to translate places 'out there' into paper forms, including maps, reports and charts on walls, that cohere with the paper world inside the boardroom. Meanwhile, Goolarabooloo people, walkers of the Trail and protectors of Country were 'there' on/with/as Country, walking the Trail, telling and listening to Bugarrigarra stories, sleeping under the stars, opening and waking up their liyan (feeling and intuitive connection) and connecting with and enlivening Country.

\section{The 'Goods' of Doing Ontologically Open Research}

Research methods, because of the metaphysics that they perform, are far from innocent. Not only do they detect, they also help to produce and amplify a particular reality (Law, 2004, p. 116). Hence, the ontological 'goods' produced by my ontologically open approach are evident in the stories/realities that were made 'visible' by the methodology I employed.

\section{Articulating a relational ontology of 'being with'}

This approach revealed the enactment of a relational ontology of 'being with' Country that was expressed by Goolarabooloo people and walkers of the Trail, in varying degrees, through their stories. ${ }^{17}$ This ontology acknowledges and relies upon the agency of the non-human world and was demonstrated through the performance of inter-subject relationships between Country and people on the Trail. Stories in the research made clear that 'being with' Country transcends cultural boundaries.

People's 'being with' Country on the Trail was performed to varying extents. Some first-time walkers of the Trail enacted their 'being with' Country through walking, listening to stories, sleeping under the stars, and becoming quiet and present to Country over the nine days of the Trail. For Goolarabooloo people others who had walked the Trail many times, and allies protecting Country, 'being with' (or as) Country was performed through mutual recognition, reciprocity of care and communicative engagement. Fundamentally, in 'being with' Country, people on the Trail recognised 'place' and the non-human entities within place, as 'living Country': a multi-dimensional actor-network of which they are a part. The three story excerpts shared below, each told by different research collaborators, elucidate the ways that different people on the Trail were being with and as Country.

17 The ontology of 'being with' emerging from this research is distinct from that presented by Martin Heidegger. A key, differentiating factor is that Heidegger's (2010) 'Being-with' (Mitsein) only extends to 'others of its kind', with Heidegger refusing to afford 'Being-with' to relationships between humans and non-human animals or humans and non-animal entities. Whilst Simon James (2009, p. 40) accepts the potential for 'Being-with' to extend to relationships between humans and nonhuman animals, he too falls short of including non-animal entities in inter-subjective encounters with humans. The research reflected an Indigenous ontology and a philosophy of 'living Country' in recognising that 'being with' can indeed be afforded to relationships between humans and non-human entities, including trees, ancestors and Country. 
Adriana, a university student and first-time walker of the Trail described her experience of walking Country with the Goolarabooloo people as a transition in how she and fellow walkers saw and related to the land:

I felt a shift ... A lot of people here l've spoken to have this feeling that the land is no longer just a landscape, but has become a living entity for them, but they can't describe in words what that actual feeling is. [For me] it's the recognition that it's not just a landscape anymore, it's living. It's a part of me and I'm also part of that cycle. [The Trail] is about reconnecting, not only with the people you walk with, but reconnecting with the land ... sleeping on the beach, seeing the stars every night. It's about placing a higher value on that. (in Emmanouil, 2016, p. 167)

For Adriana, walking the Trail led to seeing the land in new ways, as a living entity, which then enabled her to place a greater value on her feelings of connection with the land. It also helped her to realise that she could continue to see the land as a living entity and stay connected with Country, even when she left the Trail. Her shift in seeing led to new ways of relating; she saw herself as part of something bigger - living Country.

Karlien, an ally of the Goolarabooloo and protector of Country, mapped out in her storytelling the lengths she would go to protect an ancient goonj (Celtis philipensis) tree in Murdjal from the proposed gas development.

[My encounters with this tree happened] at a time when the [No Gas] campaign was really intense and I felt so strongly that I would give my life for this Country. It was at the stage where Woodside was releasing the perimeters of the Gas hub site and [at that point] it was planned to stretch south of Murdjal across the area with the tree. I thought, I'm just going stay in this tree and never move. I would stay there and no one would be able to move me. I felt like the tree also felt strongly that people needed to stand on this Country and that it would give them the energy to not move, to not be defeated. (in Emmanouil, 2016, pp. 245-6)

Karlien was prepared to defend the goonj tree and Country from the threat of clearing with her own life. Interestingly, she asserted that she would not be acting alone. Through her story, a co-creative aspect of her relationship with the goonj tree is revealed, that of people and Country working together towards a shared purpose.

Teresa, Paddy Roe's daughter and matriarch of the Goolarabooloo community, also shared with me her sense of being with and as Country. Returning to Bindinganygun to tell this story, Teresa was full of emotion; for her, being with this place evoked the presence of her parents and her deep ties to Country. Referring to herself as a 'Jabirr Jabirr girl', Teresa described the significance of this place and nearby Minariny to her sense of connection with her parents and Country.

[Those räi] [spirits] walk 'round, like us we walking around. But the old people who was in this Country, they tell [mum and dad], there's spirit girls in this Country. When my mum and dad was walking around here, they found us. They found me first, spirit children. Spirit go anywhere, walk around anywhere. I think in this Country now all the räi [are] in here. The spirit must be here, in this Country, Bindinyangun.

Well this is our spirit Country, now where my mum and dad find me and my little sister. [My dad and mum] come from two different languages, Nyigina and Karajeri. 
My father see [two] Jabirr Jabirr girls and then they walked from this Country to old station, Denham Station. Mum was pregnant for me, I was born there. My little sister followed me from here, so we both born in Waterbank, in Denham Station. We been bush girls all our life.

Well, most [old] people said [to my mum and dad] that you got a spirit from this Country now, you gonna have two daughters. That's all they gave them, two daughters from this Country, me and my younger sister. And so mummy got me from there and my little sister followed me, to old Denham Station.

If no Trail you know, l'd still come back to this Country, 'cause this Country will bring me back ... When I feel lonely, thinking where to go and fish, l'll come right up here and I feel good and then I go back home. Shed tears around this place then go back home, because he remind me of my mum and dad. 'Cause my mum and dad found those two girls, from the last old people who was walking this Country. (in Emmanouil, 2016, pp. 196-195)

Teresa's relationship with Bindinganygun and Minariny stems from a particular type of connection - a räi (spirit) connection - that keeps bringing her back to this Country. This story about Teresa and her sister's räi coming from Jabirr Jabirr country, is one of many that underpins the Goolarabooloo family's sense of place; their being with, and perhaps more aptly, being as Country. ${ }^{18}$

Collectively, Teresa, Karlien and Adriana demonstrate that people on the Trail were being with and as Country by seeing the land as 'Country', a living entity with which a person might collaborate and allow themselves to be affected by (e.g. being called back to Country and feeling compelled to protect Country). These realities were detected and made visible through the research because of the ontologically open approaches used.

\section{Ontological shifts}

While an ontology of being with and being as Country was unquestioned by Goolarabooloo people involved in the research, I, and other walkers on the Trail needed to undergo an ontological shift in how we conceived of 'place' in order to experience 'living Country' and co-creating/becoming as a reality. These ontological shifts were significant; what walkers of the Trail felt and saw had the potential to change them and to alter what they sensed. This broader realisation of collaborating with and perhaps as 'living Country' by more than Indigenous peoples has big implications for the ontological politics enacted in place. It is significant because it demonstrates what would be - for most non-Indigenous people - a new, different kind of connecting and knowing with/as Country and that shared ways of understanding and relating with/as Country are possible. Walking the Lurujarri Dreaming Trail offered non-Indigenous people an opportunity to question what might be their 'colonising gaze' towards the land, and to foster 'new' or different ways of seeing and relating to place that respect Indigenous ways of being and knowing.

18 The Bawaka Collective (see Country et al., 2016) articulate being as Country as a co-becoming through which 'being is constituted through relationships that are constantly re-generated ... [whereby] more-than-humans and humans co-become as place/space, in deep relation to all the diverse co-becomings' (p. 456). 


\section{Texts that make difference visible}

Another 'good' produced by this ontologically oriented research is this paper; a text that reveals and connects to the experiences of those who have walked the Trail. This text does not ignore or refuse difference. It makes visible a radically different experience of place than would have been had elsewhere. This is what ontologically open empirical research needs to do, allow for and keep difference (Verran, 2013), particularly in the analysis. The challenge of writing an academic text is remaining true to the differences and tensions of the field; this must be realised each and every time research is practiced (Verran, 2013).

\section{Dialogue}

In using ontological openness as a research methodology I was able to work respectfully, ethically and productively with the different and divergent realities being performed on the Lurujarri Dreaming Trail. This approach allowed for ontological and epistemological pluralism and hence, offered a means for decolonising knowledge production. 'Working together' knowledge systems gave me the capacity to recognise the different way that place was being enacted on the Trail; an alternate reality that contested the version of place being 'done' by the WA Government and mining corporations: people-place as living Country. Perhaps most significantly to the people and Country involved in this research, my adoption of this approach enabled me to perpetuate the political statement of the Trail, in the face of a significant conflict over place.

Not only did the methods employed within this research ensure that multiple realitities were made 'visible', they also supported respectful dialogue between different types of realities (ones that are often called 'Indigenous' and 'Western'). The capacity for this methodology to support dialogue through 'working together' knowledge systems presents an opportunity for others working in cross-cultural research contexts to take seriously the multiple and divergent realities that people, Indigenous and non-Indigenous, and place perform in relationship. 


\section{References}

Addelson, K. P. (1994). Moral passages: toward a collectivist moral theory. New York: Routledge.

Banting, P. (2013). The Ontology and Epistemology of Walking: Animality in Karsten Heuer's Being Caribou: Five Months on Foot with an Arctic Herd. In E. Soper \& N. Bradley (Eds.), Greening the Maple: Canadian ecocriticism in context (pp. 407-431). Calgary: University of Calgary Press.

Benterrak, K., Muecke, S., \& Roe, P. (1984). Reading the country. Fremantle: Fremantle Arts Centre Press.

Bessarab, D. (2008). Country is lonely. In S. Morgan, T. Mia, \& B. Kwaymullina (Eds.), Heartsick for Country: stories of love, spirit and creation (pp. 44-58). Fremantle: Fremantle Press.

Bradley, J., \& Yanyuwa families. (2010). Singing saltwater country. Crows Nest: Allen \& Unwin.

Bradshaw, E., \& Fry, R. (1989). A management report for the Lurujarri Heritage Trail, Broome, Western Australia. Perth: Western Australian Museum.

Brearley, L. (2010). Gulpa ngawal: Indigenous deep listening. Melbourne: RMIT.

Burarrwanga, L., Ganambarr, R., Ganambarr-Stubbs, M., Ganambarr, B., Maymuru, D., Wright, S., . . . Lloyd, K. (2013). Welcome to my Country. Crows Nest: Allen \& Unwin.

Christie, M. (2007). Yolnu language habitat: ecology, identity and law in Aboriginal society. In G. Leitner \& I. Malcolm (Eds.), The habitat of Australia's Aboriginal languages: past, present and future. Berlin: Mouton de Gruyter.

Country, B., Wright, S., Suchet-Pearson, S., Lloyd, K., Burarrwanga, L., Ganambarr, R., . . Sweeney, J. (2016). Co-becoming Bawaka: Towards a relational understanding of place/space. Progress in Human Geography, 40(4), 455-475.

Country, B., Wright, S., Suchet-Pearson, S., Lloyd, K., Burarrwanga, L., Ganambarr, R., . . Maymuru, D. (2015). Working with and learning from Country: decentring human author-ity. Cultural Geographies, 22(2), 269- 283.

Dodson, P. (2007). Whatever happened to reconciliation? In J. Altman \& M. Hinkson (Eds.), Coercive reconciliation: stabilise, normalise, exit Aboriginal Australia (pp. 21-30). North Carlton, VIC: Arena Publications.

Emmanouil, O. (2016). Being with Country: the performance of people-place relationships on the Lurujarri Dreaming Trail (PhD). Darwin: Charles Darwin University.

Fenwick, T., \& Edwards, R. (2010). A way to intervene, not a theory of what to think. Actor Network Theory in Education. Abingdon: Routledge Press.

Fielbleman, J. K. (Ed.) (1960) Dictionary of philosophy (15th ed., rev. ed.). New York: New York Philosophical Library.

Ford, L. P. (2010). Aboriginal knowledge, narratives and country: marri kunkimba putj putj marrideyan. Teneriffe: Post Pressed.

Goolarabooloo. (2013). Goolarabooloo: Lurujarri Dreaming Trail. Retrieved from http://goolarabooloo.org.au

Graham, M. (2009). Understanding human agency in terms of place: a proposed aboriginal research methodology. PAN: Philosophy, Activism, Nature (6), 71-78.

Guyula, Y. (2010). The story comes along, and the children are taught. Learning Communities: International Journal of Learning in Social Contexts (2), 18-22. 
Harrison, M. D., \& McConchie, P. (2009). My people's dreaming: an Aboriginal elder speaks on life, land, spirit and forgiveness. Warreiwood: Finch Publishing.

Heidegger, M. (2010). Being and Time (J. Stambaugh, Trans.). New York: SUNY Press.

James, S. P. (2009). The presence of nature: a study in phenomenology and environmental philosophy. Hampshire: Pangrave Macmillan.

Kelly, D. (2016). James Price Point: the story of a movement. Broome: Damian Kelly.

Kwaymullina, A. (2008). Introduction: a land of many countries. In S. Morgan, T. Mia, \& B. Kwaymullina (Eds.), Heartsick for country: stories of love, spirit and creation (pp. 6-20). Fremantle: Fremantle Press.

Latour, B. (1987). Science in Action Cambridge Harvard University Press.

Latour, B. (2005). Reassembling the Social. Oxford: Oxford University Press.

Law, J. (1999). After ANT: complexity, naming, topology. In J. Law \& J. Hassard (Eds.), Actor Network Theory and After. Oxford: Blackwell Publishers, The Sociological Review Monograph.

Law, J. (2004). After Method: mess in social science research. Oxon: Routledge.

Law, J. (2009). Actor network theory and material semiotics. In B. S. Turner (Ed.). The New Blackwell Companion to Social Theory. Oxford: Blackwell.

Maybury-Lewis, D. (Writer). (1992). Millennium: Tribal Wisdom and the Modern World. In B. P. L. BBCTV, Adrian Malone Productions Limited, KCET, and The Global Television Network (Producer): BBC-TV.

Mowaljarlai, D., \& Malnic, J. (1993). Yorro Yorro: Aboriginal creation and the renewal of nature. Broome: Magabala Books.

Muecke, S. (2017). Earthbound Law: The Force of an Indigenous Australian Institution. Law Critique, 1-9.

Neidjie, B. (1989). Story about feeling. Broome: Magabala Books.

Nicholls, A. V. (2009). The social life of the computer in Ramingining (PhD). Darwin: Charles Darwin University.

Roe, P., \& Hoogland, F. (1999). Black and white, a trail to understanding. In J. Sinatra \& P. Murphy (Eds.), Listen to the People, Listen to the Land (pp. 11-30). Carlton: Melbourne University Press.

Rose, D. B. (1988). Exploring an Aboriginal land ethic. Meanjin, 47(3), 378-387.

Rose, D. B. (1996). Nourishing terrains: Australian Aboriginal views of landscape and wilderness. Canberra: Australian Heritage Commission.

Rose, D. B. (2000). Dingo makes us human. Cambridge, UK: Cambridge University Press.

Rose, D. B. (2002). Indigenous ecologies and an ethic of connection. In N. Low (Ed.), Global Ethics and Environment (pp. 175-187). London; New York: Routledge.

Rose, D. B. (2004). Reports from a wild country: ethics for decolonisation. Sydney: UNSW Press.

Sandefur, J. R. (1986). Kriol of North Australia: a language coming of age. Darwin: Summer Institute of Linguistics.

Smith, L. T. (2012). Decolonizing methodologies: research and indigenous peoples (Second ed.). London: Zed Books.

Turner, M. K. (2010). Iwenhe Tyerrtye: what it means to be an Aboriginal person. Alice Springs: IAD Press. 
Verran, H. (1998). Re-imagining land ownership in Australia. Postcolonial Studies, 1(2), 237- 254.

Verran, H. (2007). Metaphysics and learning. Learning Inquiry, 1(1), 31-39.

Verran, H. (2013). Engagements between disparate knowledge traditions: Toward doing difference generatively and in good faith. In L. Green (Ed.), Contested Ecologies: dialogues in the south on nature and knowledge (pp. 141-161). Cape Town, South Africa: Human Sciences Research Council Press.

Whitmont, D. (2010). Rush to Riches. Four Corners http://www.abc.net.au/4corners/content/2010/ s2933084.htm: Australian Broadcasting Corporation.

Wilcox QC, M. (2010). Kimberley at the crossroads: the case against the gas plant. Broome, WA: Save the Kimberley P/L.

Wilson, L., \& Ellender, I. (2002). Aboriginal versus European perspectives on country. PAN: Philosophy, Activism, Nature, 2, 55-62.

Wilson, S. (2008). Research is ceremony: indigenous research methods. Winnipeg: Fernwood Publishers.

Wright, S., Lloyd, K., Suchet-Pearson, S., Burarrwanga, L., Tofa, M., \& Bawaka, C. (2012). Telling stories in, through and with Country: engaging with Indigenous and more-than-human methodologies at Bawaka, NE Australia. Journal of Cultural Geography, 29(1), 39-60. 